\title{
Effects of Plant Growth Regulators on Root Culture and Yeast Extract Elicitation on Metabolite Profiles of Polygonum minus
}

(Kesan Pengawalatur Pertumbuhan ke atas Kultur Akar dan Elisitasi Ekstrak Yis ke atas Profil Metabolit Sekunder Polygonum minus)

\author{
MOHD AZHAR HASSAN*, MARIATUlQABTIAH ABDUl RAZAK, AHMAD HAFIZ BAHAROM, \\ MUHAMMAD SHAFIE MD SAH \& MOHAMAD ZULKIFFELY A. RAHMAN
}

\begin{abstract}
There are various secondary metabolites that have been identified in Polygonum minus Huds. or kesum plant, but the production is often very low and depending on growth stage. Therefore, elicitation and in vitro techniques have been suggested as an effective way for inducing secondary metabolites production in plant. This study was conducted to determine the optimal conditions for P. minus root formation in vitro and to profile the metabolite content from P. minus root culture with and without elicitor treatment. From the root induction study, it was found that the fresh weight of induced root for nodal explant in MS liquid media supplemented with $0.5 \mathrm{mg} / \mathrm{L} \mathrm{NAA}$ and shaken had the highest production $(0.38 \pm 0.08 \mathrm{~g})$ compared to other treatments including the control. The results from metabolite profile showed that the volatile compound of $\mathrm{P}$. minus root produced without any elicitation contained $50.11 \%$ aliphatic (27.59\% aldehide, $9.17 \%$ alkane and $13.35 \%$ others) and $19.39 \%$ sesquiterpene ( $\beta$-caryophyllene, $\alpha$-bergamotene, $\beta$-farnesene, $\alpha$-caryophyllene dan $\beta$-curcumene) where the dodecanal compound (22.27\%) and $\beta$-caryophyllene $(8.09 \%)$ have the highest percentage value for aliphatic and sesquiterpene group, respectively. Moreover, elicitation of P. minus root culture using yeast extract at $100 \mathrm{mg} / \mathrm{L}$ concentration for 1 day demonstrated the ability to increase the production of secondary metabolites in many volatile compounds of kesum in vitro root including the sesquiterpene compounds compared to control treatment and other yeast extract elicitation treatments.
\end{abstract}

Keywords: Aliphatic; elicitation; Polygonum minus; secondary metabolite; sesquiterpene

ABSTRAK

Terdapat pelbagai metabolit sekunder dikenal pasti di dalam Polygonum minus Huds. atau kesum tetapi penghasilannya sangat rendah dan bergantung pada peringkat pertumbuhan. Oleh itu, teknik elisitasi dan in vitro telah dicadangkan sebagai cara yang berkesan untuk merangsang pengeluaran metabolit sekunder pada tumbuhan. Kajian ini dilakukan bagi menentukan keadaan yang optimum bagi penghasilan akar P. minus secara in vitro dan memprofil kandungan metabolit daripada kultur akar P. minus dengan dan tanpa perlakuan elisitor. Hasil kajian pengaruhan akar mendapati bahawa berat basah akar bagi eksplan nodal di dalam medium MS cecair yang ditambah dengan 0.5 mg/L NAA dan digoncang telah memberikan nilai hasilan yang paling tinggi $(0.38 \pm 0.08 \mathrm{~g})$ berbanding rawatan lain termasuk rawatan kawalan. Keputusan kajian profil metabolit pula menunjukkan bahawa sebatian meruap akar P. minus yang terhasil tanpa sebarang perlakuan elisitor terdiri daripada $50.11 \%$ alifatik $(27.59 \%$ aldehid, $9.17 \%$ alkana dan $13.35 \%$ lain-lain) dan $19.39 \%$ sesquiterpena ( $\beta$-kariofilena, $\alpha$-bergamoten, $\beta$-farnesen, $\alpha$-kariofilena dan $\beta$-curcumen) dengan sebatian dodekanal (22.27\%) dan $\beta$-kariofilena (8.09\%) masing-masing menunjukkan nilai peratusan paling tinggi bagi kumpulan alifatik dan sesquiterpena. Manakala elisitasi kultur akar P. minus menggunakan ekstrak yis pada kepekatan $100 \mathrm{mg} / \mathrm{L}$ selama 1 hari didapati berupaya meningkatkan penghasilan metabolit sekunder dalam kebanyakan sebatian meruwap akar kesum yang terhasil termasuklah pada sebatian sesquiterpena berbanding dengan rawatan kawalan dan rawatan elisitasi ekstrak yis yang lain.

Kata kunci: Alifatik; elisitasi; metabolit sekunder; Polygonum minus; sesquiterpena

\section{INTRODUCTION}

Plants can produce various secondary metabolites under specific conditions. These compounds play a role in adapting plants with environment including biotic and abiotic pressure (Rao \& Ravishankar 2002). Secondary metabolites are usually produced by plants as defence systems against insects, herbivores and pathogens such as viruses, bacteria and fungi. They also protect plants from abiotic pressures such as drought, salinity, UV light, heavy metals, extreme temperatures and nutrient deficiency in the soil (Ismail et al. 2011). Other functions of secondary metabolites include as attractants of pollinators for plant 
reproduction, signaling molecules and as hormones in secondary metabolism of plant cells (Korkina 2007). To date, thousands of different secondary metabolite structures have been identified in plants. Previous studies have identified 77 metabolites in the essential oil of $P$. minus leaf where most of them (76.59\%) were aliphatic compounds, which contributes to the aroma and taste of the plant (Ahmad et al. 2014; Yaacob 1987).

The secondary metabolite content in the plant is often very low and depends on growth stage (Neumann et al. 2009; Poulev et al. 2003). Therefore, elicitation and in vitro techniques have been proposed as an effective way for generating high secondary metabolites in plants within a shorter time duration (Gor et al. 2011; Rao \& Ravishankar 2002; Zhao et al. 2005). Elicitation of Solenostemon scutellarioides using methyl jasmonate, MeJA $(50 \mu \mathrm{M})$ and salicylic acid, SA $(50 \mu \mathrm{M})$ increased rosmarinic acid by 1.7 and 1.4 times, respectively, on the first day while elicitation using yeast extract $(100 \mu \mathrm{g} /$ $\mathrm{mL}$ ) showed high content of rosmarinic acid (1.5 times) on the third day (Sahu et al. 2013). Few new compounds such as 2,2'-bioxirane, propanoic acid-2oxo-methyl ester, repandin A, 2-propanone, 1,3-dihydroxy-imidazolidine2,4,5-trione and 2-acetyl-2-hydroxy-butyrolactone have been found in cell culture of $P$. minus treated with elicitors but not found in control culture (Vikram et al. 2014).

Polygonum minus Huds. or kesum is a popular aroma herb belongs to family of Polygonaceae. Various metabolites are produced by $P$. minus cell culture in a medium elicited by various concentrations of jasmonic acid (JA), SA, yeast extract and glass beads with different incubation times including 2-furancarboxaldehyde, 5-hydroxymethylfurfural and 2-cyclopenten-1-one-2hydroxy (Shukor et al. 2013). However, no studies were conducted on elicitation of $P$. minus root culture using yeast extract and determination of optimum culture media for producing $P$. minus in vitro root. Therefore, this study was carried out aiming at determining the optimal conditions for $P$. minus root formation and profiling the metabolite content from the in vitro root culture of $P$. minus resulted from yeast extract elicitation and without elicitation.

\section{MATERIALS AND METHODS}

\section{IN VITRO PROPAGATION OF POLYGONUM MINUS}

The sterile plants of Polygonum minus were obtained from the Plant Biotechnology Laboratory, Universiti Kebangsaan Malaysia. The selected nodal of sterile plant was cut by $2.0 \mathrm{~cm}$ using scalpel and subcultured into a tissue culture jar bottle containing Murashige and Skoog (MS) media. Each bottle was placed with seven nodal explants. All subcultured explants were placed in a culture room of 25 $\pm 2^{\circ} \mathrm{C}$ temperature with a $16 \mathrm{~h}$ photoperiod pendaflour light. Subcultures on fresh media were performed every 2 months to ensure sufficient explant sources.

\section{IN VITRO ROOT INDUCTION}

In vitro root induction was performed by placing $2.0 \mathrm{~cm}$ sterile nodal explants on the MS liquid media containing different types and concentrations of auxin, which were $\alpha$-naphthalene acetic acid (NAA: 0.5, 1.0, 1.5 and $2.0 \mathrm{mg} / \mathrm{L}$ ) and Indole-3-butyric acid (IBA: 0.5, 1.0, 1.5 and $2.0 \mathrm{mg} / \mathrm{L}$ ). Each bottle jar was placed with three nodal explants. Liquid and solid MS media without plant growth regulators were used as control treatments in the experiment. All these treatment and control cultures were grown in static or shake condition on an orbital shaker ( $80 \mathrm{rpm})$ in a culture room at $25+2{ }^{\circ} \mathrm{C}$ under $16 \mathrm{~h}$ photoperiod pendaflour light. This study utilised a randomised complete block design (RCBD) with 3 replications where each replication contains 5 jar bottles per treatment.

\section{DATA COLLECTION AND STATISTICAL ANALYSIS}

Data for root length $(\mathrm{cm})$, root weight $(\mathrm{g})$ and root quality were recorded after the explant reached 2 months old. Statistical analysis was determined by one-way Analysis of Variance (ANOVA) using Statistic Analysis Software 9.4 programme (SAS 9.4). Analysis was carried out using Duncan's Multiple Range Test (DMRT).

\section{ELICITATION OF YEAST EXTRACT}

Two-month-old seedlings were transplanted into jar bottles containing MS liquid media with different concentrations (100 and $250 \mathrm{mg} / \mathrm{L}$ ) of yeast extract for elicitation, with control seedlings having no elicitor $(0 \mathrm{mg} / \mathrm{L})$. At the same time, control seedlings were transferred into jar bottles containing MS liquid media without elicitor. Then, P. minus seedlings were picked up on day 1 and 3 to perform a volatile compounds analysis using Gas Chromatography - Mass Spectrometry (GC-MS). Each experiment comprised three replications. Factorial experimental design of $3 \times$ 2 (yeast extract concentration $\times$ elicitation period) was applied in this study.

\section{EXTRACTION OF SECONDARY METABOLITES}

Approximately, $2 \mathrm{~g}$ of $P$. minus root from the control and the treatment samples were separated from the seedlings for each elicitation. The roots of P. minus were chopped with a knife until it turned into very small pieces. Then, the roots were put into the SPME (Solid Phase Microextraction) vial and closed with a sealed lid. After that, the root samples were heated at $65^{\circ} \mathrm{C}$ for $15 \mathrm{~min}$ in the heating block. The vapour formed was collected by penetrating the SPME needle through the sealed lid. The SPME fibre $(100 \mu \mathrm{m}$ polydimethylsiloxane, PDMS) contained in the needle was extended into the space of sample closure area for absorbing the volatile compounds released from $P$. minus roots.

\section{GC-MS ANALYSIS}

The presence of secondary metabolites or volatile and semi-volatile compounds in the control and treated P. minus 
roots were determined by Gas Chromatography - Mass Spectrometry (GC-MS). The gas chromatography system used was Agilent Technologies Model 5975C with nonpolar DB-5MS columns ( $30 \mathrm{~m}$ length $\times 0.25 \mathrm{~mm}$ diameter) and film thickness of $0.25 \mu \mathrm{m}$. The GC-MS analysis parameters were set as in Table 1. The compounds detected by the mass spectrometry was compared with the data in GC-MS NIST library based on similarity index (SI) unit and retention time (RT). Only volatile compounds with SI unit higher than 80 and were consistently present in two or more replications accepted for subsequent analysis.

\section{RESULTS AND DISCUSSION}

\section{EFFECTS OF PLANT GROWTH REGULATORS ON IN VITRO ROOT PRODUCTION OF POLYGONUM MINUS}

In general, auxin additions in growth media cause changes in protein synthesis and RNA production that can stimulate growth and rapid cell division to increase the number of roots (Davies 2013; Husen \& Pal 2007). The effects of various types and concentrations of auxin (NAA and IBA) have been studied to determine and develop optimal culture media for producing $P$. minus roots in vitro.

The fresh weight of induced root produced by the explant is influenced by the type and concentration of plant growth regulators (PGR) used in media. For instance, fresh weight of induced root for nodal explants in liquid MS media supplemented with $0.5 \mathrm{mg} / \mathrm{L} \mathrm{NAA}$ and shaken demonstrated the highest production $(0.38 \pm 0.08 \mathrm{~g})$ compared to other treatments including control treatment (Table 2). Similar results have been reported in the Ophiorrhiza prostrata (Martin et al.2008), Kaempferia galanga and Kaempferia rotunda (Geetha et al. 2015).

Like NAA, IBA also showed the highest fresh weight of induced root in the concentration of $0.5 \mathrm{mg} / \mathrm{L}$ on shaking media condition, which was $0.34 \pm 0.07 \mathrm{~g}$. However, its fresh weight value was lower than that of NAA. The same result also recorded between NAA and IBA with 1.0 $\mathrm{mg} / \mathrm{L}$ concentration where the NAA showed higher root production than IBA. According to Hartmann et al. (2007), IBA is the strongest, stable and less toxic of auxin that is widely used as a root booster hormone for most species such as Clinacanthus nutans (Chen et al. 2015) and
Wattakaka volubilis (Vinothkumar \& Senthilkumar 2015). However, NAA is stated to be the most suitable auxin for in vitro rooting of nodal explants for some plant species including Ophiorrhiza prostrata (Martin et al. 2008) and Citrus tangerina (Nwe et al. 2014). There were also some species showing the same rooting response to NAA and IBA like Punica granatum where MS media at full strength containing $0.5 \mathrm{mg} / \mathrm{L}$ NAA and $0.5 \mathrm{mg} / \mathrm{L}$ IBA showed the best rooting results, respectively (Singth et al. 2014). The combination of both NAA and IBA hormones is very successful for some species in in vitro root production; for example, on the rooting of Eriobotrya japonica (Abbasi et al. 2013).

Normal weight of fresh roots that decreased when the NAAconcentration increases from 0.5 to $2.0 \mathrm{mg} / \mathrm{L}$ indicates that the effect of inhibition from using high concentration of plant growth regulator. This phenomenon has been also reported in Mentha piperita (Ghanti et al. 2004) and Citrus tangerine (Nwe et al. 2014). Observation by Baker and Wetzstein (1994) and Rai et al. (2009) suggested that auxin at high concentration causes the production of degradative metabolites to increase and inhibit root growth processes.

The liquid media at static or shaking condition affects the root production of nodal explants. This was evidenced by the production of low fresh root weight in the liquid media, which was static rather than shaking for each NAA and IBA concentration used in this experiment including the control treatment. IBA showed a significant decrease in root weight for media that are in a static condition rather than shaking for each concentration used in the experiment. Mehrotra et al. (2007) stated that growth rate of shoot and root can be enhanced via forced aeration in liquid culture media that are continuously shaken. Continuous shaking on liquid media can produce enough oxygen supply until it finally affects the fast and plentiful growth. It also facilitates the distribution of nutrient evenly for the whole explants, which results in the best root growth.

Control treatment, which is a liquid MS media without any plant growth regulator placed in a shaking condition (C1) produced the highest fresh weight of root $(0.26 \pm 0.04$ g) compared to other two control treatments (C2 and C3). There were only two treatments in this study that produced fresh weight of root higher and significantly different compared to $\mathrm{C} 1$, which were $\mathrm{T} 1$ and $\mathrm{T} 5$ with the weights

TABLE 1. Parameters for GC-MS analysis of Polygonum minus root

\begin{tabular}{ll}
\hline Parameter & Unit \\
\hline Injector temperature & $220^{\circ} \mathrm{C}$ \\
Detector temperature & $280^{\circ} \mathrm{C}$ \\
Column temperature & $50^{\circ} \mathrm{C}, 3 \mathrm{~min} ; 20^{\circ} \mathrm{C} / \mathrm{min}-100^{\circ} \mathrm{C}, 3 \mathrm{~min} ;$ \\
& $30^{\circ} \mathrm{C} / \mathrm{min}-250^{\circ} \mathrm{C}, 3 \mathrm{~min}$. \\
Flow rate & $1.3 \mathrm{~mL} / \mathrm{min}$ \\
Injection volume & $1 \mu \mathrm{L}$ \\
Injection method & Splitless \\
Mass spectrometry & Scan mode $(\mathrm{m} / \mathrm{z}$ range $=55-355)$ \\
\hline
\end{tabular}


TABLE 2. Means from DMRT for length and fresh weight of in vitro root of Polygonum minus in different types and concentrations of plant growth regulators with different media condition

\begin{tabular}{|c|c|c|c|c|c|c|}
\hline \multicolumn{5}{|c|}{ Treatment } & \multicolumn{2}{|c|}{ Score } \\
\hline \multirow[t]{2}{*}{ Code } & \multicolumn{2}{|c|}{$\begin{array}{l}\text { Plant growth } \\
\text { regulator }(\mathrm{mg} / \mathrm{L})\end{array}$} & \multirow[t]{2}{*}{$\begin{array}{l}\text { Media } \\
\text { form }\end{array}$} & \multirow[t]{2}{*}{$\begin{array}{c}\text { Media } \\
\text { condition }\end{array}$} & \multirow[t]{2}{*}{$\begin{array}{l}\text { Mean of in vitro root } \\
\text { fresh weight }(\mathrm{g})\end{array}$} & \multirow[t]{2}{*}{$\begin{array}{c}\text { Mean of in vitro root } \\
\text { length }(\mathrm{cm})\end{array}$} \\
\hline & NAA & IBA & & & & \\
\hline $\mathrm{T} 1$ & 0.5 & 0 & Liquid & Shake & $0.38 \pm 0.08^{\mathrm{a}}$ & $7.60 \pm 1.61^{\mathrm{f}}$ \\
\hline $\mathrm{T} 2$ & 1.0 & 0 & Liquid & Shake & $0.28 \pm 0.06^{\mathrm{c}}$ & $8.20 \pm 0.86^{\mathrm{ef}}$ \\
\hline $\mathrm{T} 3$ & 1.5 & 0 & Liquid & Shake & $0.24 \pm 0.06^{\mathrm{ce}}$ & $5.57 \pm 0.82^{\mathrm{g}}$ \\
\hline $\mathrm{T} 4$ & 2.0 & 0 & Liquid & Shake & $0.18 \pm 0.05^{\mathrm{fg}}$ & $5.07 \pm 0.62^{\mathrm{g}}$ \\
\hline $\mathrm{T} 5$ & 0 & 0.5 & Liquid & Shake & $0.34 \pm 0.07^{\mathrm{b}}$ & $10.87 \pm 1.05^{\mathrm{bc}}$ \\
\hline T6 & 0 & 1.0 & Liquid & Shake & $0.21 \pm 0.05^{\mathrm{ef}}$ & $10.67 \pm 1.06^{\mathrm{c}}$ \\
\hline $\mathrm{T} 7$ & 0 & 1.5 & Liquid & Shake & $0.25 \pm 0.05^{\mathrm{cd}}$ & $11.73 \pm 1.39^{\mathrm{b}}$ \\
\hline $\mathrm{T} 8$ & 0 & 2.0 & Liquid & Shake & $0.17 \pm 0.02^{\mathrm{g}}$ & $9.40 \pm 1.06^{\mathrm{d}}$ \\
\hline T9 & 0.5 & 0 & Liquid & Static & $0.21 \pm 0.06^{\mathrm{ef}}$ & $4.77 \pm 0.59^{\mathrm{g}}$ \\
\hline $\mathrm{T} 10$ & 1.0 & 0 & Liquid & Static & $0.22 \pm 0.04^{\text {de }}$ & $7.73 \pm 0.90^{\mathrm{f}}$ \\
\hline $\mathrm{T} 11$ & 1.5 & 0 & Liquid & Static & $0.17 \pm 0.03^{\mathrm{g}}$ & $5.10 \pm 0.78^{\mathrm{g}}$ \\
\hline $\mathrm{T} 12$ & 2.0 & 0 & Liquid & Static & $0.13 \pm 0.03^{\mathrm{hi}}$ & $4.77 \pm 1.33^{\mathrm{g}}$ \\
\hline $\mathrm{T} 13$ & 0 & 0.5 & Liquid & Static & $0.07 \pm 0.03^{\mathrm{j}}$ & $2.63 \pm 0.95^{\mathrm{hi}}$ \\
\hline $\mathrm{T} 14$ & 0 & 1.0 & Liquid & Static & $0.08 \pm 0.02^{\mathrm{j}}$ & $3.20 \pm 0.56^{\mathrm{hi}}$ \\
\hline $\mathrm{T} 15$ & 0 & 1.5 & Liquid & Static & $0.07 \pm 0.03^{\mathrm{j}}$ & $3.53 \pm 0.85^{\mathrm{h}}$ \\
\hline T16 & 0 & 2.0 & Liquid & Static & $0.03 \pm 0.02^{\mathrm{k}}$ & $2.43 \pm 1.25^{\mathrm{i}}$ \\
\hline $\mathrm{C} 1$ & 0 & 0 & Liquid & Shake & $0.26 \pm 0.04^{\mathrm{cd}}$ & $7.47 \pm 0.83^{\mathrm{f}}$ \\
\hline $\mathrm{C} 2$ & 0 & 0 & Liquid & Static & $0.16 \pm 0.04^{\mathrm{gh}}$ & $8.77 \pm 0.78^{\mathrm{de}}$ \\
\hline $\mathrm{C} 3$ & 0 & 0 & Solid & Static & $0.10 \pm 0.03^{\mathrm{ij}}$ & $13.80 \pm 1.29^{\mathrm{a}}$ \\
\hline
\end{tabular}

Means within a column with the same letters are not significantly different at $p<0.0001$ according to DMRT

of $0.38 \pm 0.08$ and $0.34 \pm 0.07 \mathrm{~g}$, respectively. Treatments that produced a weight of roots that is not significant or lower than $\mathrm{C} 1$ were considered unsuitable as treatments of root production for $P$. minus nodal explant due to loss of cost, time and energy. Data of root fresh weight for $\mathrm{C} 3$ control treatments was lower compared to $\mathrm{C} 1$ and $\mathrm{C} 2$ suggesting that the root production of $P$. minus nodal explant was more suitable in liquid rather than solid media. Liquid media allows a closer relationship between media and tissue in which it can stimulate and facilitate nutrient and hormone uptake resulting in improved shoot and root growth (Sandal et al. 2001).

Table 2 also illustrates that root length was not the only factor contributing to the fresh weight of the root produced. For instance, the $\mathrm{C} 3$ control treatment produced the longest root of $13.8 \pm 1.29 \mathrm{~cm}$ compared to the other treatments, but the fresh weight of its root was recorded among the lowest. Although T1 treatment produced a relatively moderate root length of $7.6 \pm 1.61 \mathrm{~cm}$ compared to the other treatments, the fresh weight of the root recorded was the highest among the others. This proved that other factors such as the number and thickness of the root produced can give an impact on the fresh weight of the root recorded.

The results in Table 3 displays that the roots characters in all treatments media including control in shacking condition were thick, long and dark in colour (Figure 1(A)) except for the treatment of T3 and T4 where the root character was clump (Figure 1(B)). When in static condition, the in vitro roots formed for all treatments media were thin, short and bright in colour (Figure 1(C)) except for treatment T12 where the root character was clump. According to Davies and Joiner (1980), high concentration of NAA can affect the quality and shape of the root produced. The root elongation phase is highly responsive to auxin concentration where it can inhibit root elongation at high concentration (Baker \& Wetzstein 1994; Hu \& Wang 1983) resulted from ethylene production within the root zone that acts as an inhibitor agent (Chang et al. 2013). Situation in the treatment of T3 and T4 also occurred in Mentha piperita where the resulting root length decreased when the NAA concentrations used exceeds 1.0 $\mathrm{mg} / \mathrm{L}$ (Ghanti et al. 2004).

\section{EXTRACTION OF VOLATILE COMPOUNDS FROM POLYGONUM MINUS IN VITRO ROOT}

The chemical composition of volatile compounds from P. minus has been identified since 1987 (Yaacob 1987). Subsequently, more studies on $P$. minus have been conducted discovering more volatile compounds such as in the study of Huda-Faujan et al. (2009), Vikram et al. (2014) and Vimala et al. (2006). In addition, chemical composition for essential oils from other species such as Polygonum odoratum was studied by Vietnamese (Dung et al. 1995) and Australia chemists (Hunter et al. 1997). Some studies have been able to identify valuable compounds from the roots of two Polygonum genus such as phytoestrogens in Polygonum cuspidatum (Matsuda et al. 2001) and indigo in Polygonum tinctorium (YoungAm et al. 2000). To date, there is only one study reported on the chemical composition of the volatile compound 
TABLE 3. Root characters of Polygonum minus in different types and concentrations of plant growth regulators with different media condition

\begin{tabular}{|c|c|c|c|c|c|}
\hline \multicolumn{5}{|c|}{ Treatment } & \multirow{3}{*}{$\begin{array}{c}\text { Score } \\
\text { Root } \\
\text { characters }\end{array}$} \\
\hline \multirow[t]{2}{*}{ Code } & \multicolumn{2}{|c|}{$\begin{array}{l}\text { Plant growth } \\
\text { regulator }(\mathrm{mg} / \mathrm{L})\end{array}$} & \multirow[t]{2}{*}{$\begin{array}{l}\text { Media } \\
\text { form }\end{array}$} & \multirow[t]{2}{*}{$\begin{array}{c}\text { Media } \\
\text { condition }\end{array}$} & \\
\hline & NAA & IBA & & & \\
\hline $\mathrm{T} 1$ & 0.5 & 0 & Liquid & Shake & Thick \\
\hline $\mathrm{T} 2$ & 1.0 & 0 & Liquid & Shake & Thick \\
\hline $\mathrm{T} 3$ & 1.5 & 0 & Liquid & Shake & Thick and clump \\
\hline $\mathrm{T} 4$ & 2.0 & 0 & Liquid & Shake & Thick and clump \\
\hline $\mathrm{T} 5$ & 0 & 0.5 & Liquid & Shake & Thick \\
\hline T6 & 0 & 1.0 & Liquid & Shake & Thick \\
\hline $\mathrm{T} 7$ & 0 & 1.5 & Liquid & Shake & Thick \\
\hline $\mathrm{T} 8$ & 0 & 2.0 & Liquid & Shake & Thick \\
\hline T9 & 0.5 & 0 & Liquid & Static & Thin \\
\hline T10 & 1.0 & 0 & Liquid & Static & Thin \\
\hline $\mathrm{T} 11$ & 1.5 & 0 & Liquid & Static & Thin \\
\hline $\mathrm{T} 12$ & 2.0 & 0 & Liquid & Static & Thin and clump \\
\hline $\mathrm{T} 13$ & 0 & 0.5 & Liquid & Static & Thin \\
\hline $\mathrm{T} 14$ & 0 & 1.0 & Liquid & Static & Thin \\
\hline $\mathrm{T} 15$ & 0 & 1.5 & Liquid & Static & Thin \\
\hline $\mathrm{T} 16$ & 0 & 2.0 & Liquid & Static & Thin \\
\hline $\mathrm{C} 1$ & 0 & 0 & Liquid & Shake & Thick \\
\hline $\mathrm{C} 2$ & 0 & 0 & Liquid & Static & Thin \\
\hline C3 & 0 & 0 & Solid & Static & Thin \\
\hline
\end{tabular}
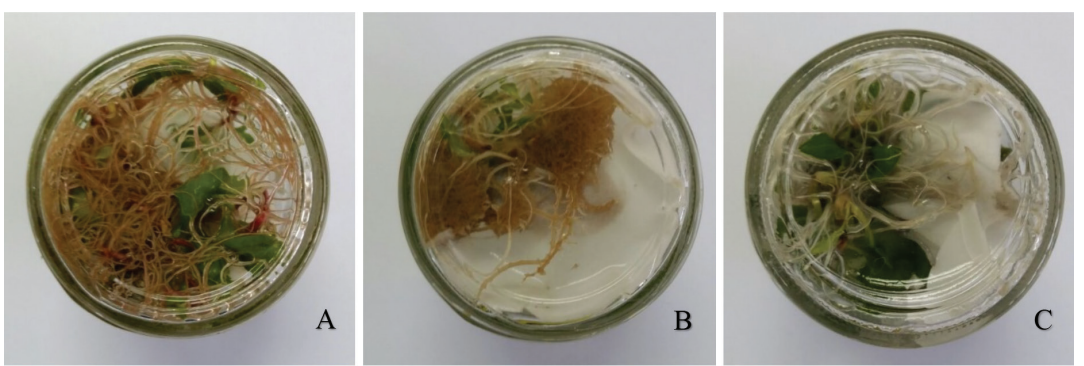

FIGURE 1. Root characters of Polygonum minus: A) Thick, long and dark colour; B) Clump; C) Thin, short and bright colour

on $P$. minus in vitro root, which uses jasmonic acid as the elicitor (Ismail et al. 2011). Therefore, in this study, the metabolite profile before treatment of the P. minus in vitro root was done for comparison purposes, in terms of type (qualitative) and composition (quantitative) of small molecules $(\mathrm{MW}<1000 \mathrm{Da})$ before different elicitation treatments are performed. Elicitors such as SA and MeJA have showed the induction of some compounds including galantamine in Lycoris radiate elicited by MeJA (Jiang et al. 2011) and taxol in the suspension culture of Taxus chinensis var. mairei elicited by SA (Wang et al. 2007). Our findings also allow metabolomics comparison between different organs or conditions of $P$. minus. For example, Shukor et al. (2013) identified 12 chemical compounds in $P$. minus leaf cell culture where these compounds do not exist in actual plant leaf.

GC-MS analysis was performed on volatile compounds of in vitro root which was collected from the $P$. minus root sample bottle through the SPME extraction technique. SPME techniques can be used for analyte extraction of various types of medium as well as for liquid and gas phase (Mitra 2004). Extraction using SPME techniques has been reported effective in metabolite extraction from in vitro roots of Polygonum multiflorum (Rong-Min et al. 2006) and cell culture of Cupressus lusitanica (De Alwis et al. 2009). A total of 60 peaks were detected in this study. Evaluation of compounds was done based on the similarity index (SI) and retention time (RT) by comparing the compounds within the NIST library. Only compounds with SI values higher than 80 were accepted for subsequent analysis (Dalluge et al. 2003). The chromatogram profile for control P. minus root is shown in Figure 2.

Analysis presents 26 compounds from 60 peaks with SI value of more than 80 and the compounds were the result of putative identification based on NIST library. These identified compounds are listed in Table 4 according 


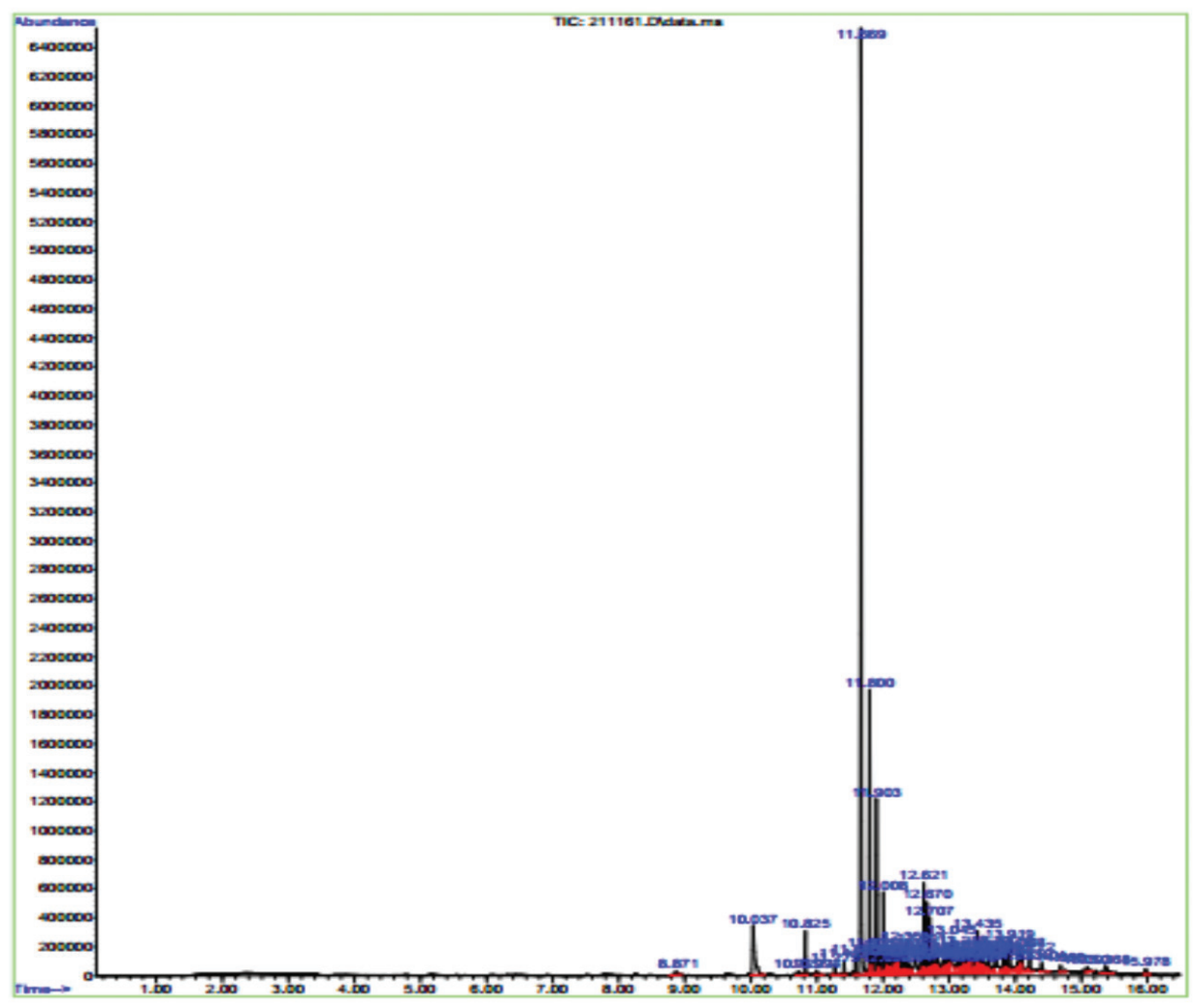

FIGURE 2. Chromatogram profile for volatile compounds from root extract of Polygonum minus without elicitation

to their retention time and relative peak area. Among the major compounds in the P. minus root extract that have been identified with high relative peak area were dodecanal (22.27\%), $\beta$-caryophyllene (8.09\%), $\beta$-farnesene $(7.15 \%)$, decanal $(3.22 \%)$ and heneicosane $(3.15 \%)$ wherein all are fragrance and flavouring agents. Meanwhile, compounds with the lowest number of peaks were undecane $(0.22 \%)$, 1-decanol $(0.37 \%)$ and tetradecane $(0.47 \%)$, which are softener, fragrance and flavour agent.

Table 4 shows that the volatile extract of $P$. minus root consisting $50.11 \%$ aliphatic $(27.59 \%$ aldehyde, $9.17 \%$ alkane and $13.35 \%$ others) and $19.39 \%$ sesquiterpene ( $\beta$-caryophyllene, $\alpha$-bergamotene, $\beta$-farnesene, $\alpha$-caryophyllene and $\beta$-curcumene). This result was different from that of previous study in which Ismail et al. (2011) reported that the volatile extract of kesum root comprised $8.65 \%$ aliphatic $(5.58 \%$ alkane and $3.07 \%$ aldehyde) and $32.85 \%$ sesquiterpene ( $\beta$-caryophyllene, trans- $\alpha$-Bergamotene, $\beta$-farnesene, $\alpha$-caryophyllene and $\alpha$-Panasinsene) where the compound with the highest relative peak area was $\beta$-caryophyllene. There are two possibilities that might cause this difference. First, the parameters used in different SPME methods produce different types of metabolites. For example, terpene extraction through the SPME method depends on parameters such as sampling time and temperature condition (Rohloff 1999). For the SPME method used in this study, compounds with high evaporation character were evaporated first compared to less volatile compounds. Second, the different apparatus and the extraction method produce different types of secondary metabolites. Types and diameter of fibre used in the SPME method affect the type of secondary metabolite produced (Schafer et al. 1995). The volatile compounds such as terpene and aldehyde are neither polar nor semi-polar having very different preference on fibre types (Rohloff 2002).

However, the results of GC-MS in this study were quite similar to that by Yaacob (1987), which reported that the essential oils of leaf and stem of kesum contained $76.59 \%$ and $56.17 \%$ aliphatic compounds where two major aliphatic compounds namely decanal (24.36\%) and dodecanal $(48.18 \%)$ have been found to be the major contributors in $P$. minus as well as side compounds such as 1-decanol, 1-dodecanol, undecanal, tetradekanal, 1-undekanol, nonanal, 1-nonanol and $\beta$-caryophyllene.

\section{EFFECTS OF YEAST EXTRACT ON PRODUCTION OF SECONDARY METABOLITES OF POLYGONUM MINUS IN VITRO ROOT}

The parameters manipulated in this elicitation study were the concentration of yeast extract and duration of treatment. Two yeast extract concentrations (100 and $250 \mathrm{mg} / \mathrm{L}$ ) and 2 treatment periods ( 1 and 3 days) were studied. These parameters were monitored to ensure that the yeast extract concentration was not too high or the duration of the treatment was not too long, thus resulting in the death of $P$. 
TABLE 4. Chemical composition of volatile compound extracts from the root of Polygonum minus without elicitation

\begin{tabular}{|c|c|c|c|}
\hline Retention time & Compound & Relative peak area $(\%)$ & Group \\
\hline 8.26 & Undecane & 0.22 & Aliphatic (Alkane) \\
\hline 10.04 & Decanal & 3.22 & Aliphatic (Aldehyde) \\
\hline 10.72 & 1-Decanol & 0.37 & Aliphatic (Other) \\
\hline 11.58 & Tetradecane & 0.47 & Aliphatic (Alkane) \\
\hline 11.67 & Dodecanal & 22.27 & Aliphatic (Aldehyde) \\
\hline 11.80 & $\beta$-caryophyllene & 8.09 & Sesquiterpene \\
\hline 11.83 & $\alpha$-bergamotene & 0.61 & Sesquiterpene \\
\hline 11.90 & $\beta$-farnesene & 7.15 & Sesquiterpene \\
\hline 12.01 & $\alpha$-caryophyllene & 2.40 & Sesquiterpene \\
\hline 12.11 & Naphthalene & 0.71 & Aliphatic (Other) \\
\hline 12.14 & Pentadecane & 1.22 & Aliphatic (Alkane) \\
\hline 12.21 & Phenol & 1.74 & Aliphatic (Other) \\
\hline 12.24 & $\beta$-curcumene & 1.15 & Sesquiterpene \\
\hline 12.30 & Naphthalene & 0.87 & Aliphatic (Other) \\
\hline 12.62 & Hexadecane & 1.46 & Aliphatic (Alkane) \\
\hline 12.71 & Tetradecanal & 2.10 & Aliphatic (Aldehyde) \\
\hline 13.00 & Sabinene hydrate & 0.84 & Aliphatic (Other) \\
\hline 13.05 & Heneicosane & 3.15 & Aliphatic (Alkane) \\
\hline 13.22 & Eicosane & 1.11 & Aliphatic (Alkane) \\
\hline 13.44 & Octadecane & 0.99 & Aliphatic (Alkane) \\
\hline 13.61 & Hexahydrofarnesyl acetone & 1.93 & Aliphatic (Other) \\
\hline 13.71 & Phthalic acid & 1.37 & Aliphatic (Other) \\
\hline 13.92 & Methyl palmitate & 1.86 & Aliphatic (Other) \\
\hline 14.10 & Dibutyl phthalate & 1.27 & Aliphatic (Other) \\
\hline 14.22 & Eicosane & 0.55 & Aliphatic (Alkane) \\
\hline 14.76 & Phytol & 2.39 & Aliphatic (Other) \\
\hline
\end{tabular}

minus sample tree. In addition, the optimum yeast extract concentration and optimum duration of treatment were determined to ensure that volatile compounds can be induced to the maximum yield level compared to control sample.

The analysed data discovered that the yeast extract elicitation was able to induce or inhibit the production of certain secondary metabolites. This has been evidenced by the study of Chen and Chen (2000) on the Salvia miltohirzia cell culture where high concentration of yeast extract was able to inhibit the production of rosmarinic acid while low concentration of yeast extract increased the production of cryptotanshinone. The compounds in Table 5 was the result of putative identification based on NIST library. The result shows that the volatile compounds produced in in vitro root of P. minus was either increased, decreased, existed or absent after elicited with the yeast extract. The results were depending on the yeast extract concentrations and elicitation period.

Table 5 presents that there were 12 compounds with the highest relative peak area on the elicitation of $100 \mathrm{mg} / \mathrm{L}$ of yeast extract for 1 day including all compounds from the sesquiterpene group representing almost half of the volatile compounds produced in the experiment. It can be concluded that to produce a high sesquiterpene compound, the in vitro root of kesum elicited with $100 \mathrm{mg} / \mathrm{L}$ of yeast extract for 1 day is particularly suitable, whereas for aldehyde production, elicitation using $100 \mathrm{mg} / \mathrm{L}$ of yeast extract for 3 days is the best.
Figure 3 shows that the highest relative peak area was recorded by dodecanal compound $(23.92 \%)$ obtained from root of $P$. minus elicited with $100 \mathrm{mg} / \mathrm{L}$ of yeast extract for 3 days. On the other hand, $\beta$-farnesene $(9.43 \%)$, $\beta$-caryophyllene $(8.74 \%)$ and $\alpha$ - caryophyllene $(3.96 \%)$ showed the highest relative peak area when elicited with $100 \mathrm{mg} / \mathrm{L}$ of yeast extract for 1 day. Several compounds were seen with a lower relative peak area of less than $1 \%$ including tetradecane, $\alpha$-bergamotene, octadecane and eicosane. Further, compounds such as tetradecane and phthalic acid did not show any difference between control and other treatments. There was also a compound produced only on certain treatments such as palmitic acid (2.77\%) and myristic acid $(1.00 \%)$, which only existed in the treatment of 250 and $100 \mathrm{mg} / \mathrm{L}$ yeast extract, respectively, for 3 days. Inhibitory production of 1-decanol compound was not affected by elicitation period but the concentration of yeast extract.

\section{CONCLUSION}

The fresh weight of P. minus in vitro root for nodal explant in shaking MS liquid media supplemented with $0.5 \mathrm{mg} / \mathrm{L}$ NAA had the highest production $(0.38 \pm 0.08 \mathrm{~g})$ compared to other treatments including the control. This proved that the fresh weight of induced root produced from the explant is influenced by the type and concentration of plant growth regulator used together with the form and position 
TABLE 5. Relative peak area of volatile compounds of Polygonum minus root after elicitation by yeast extract

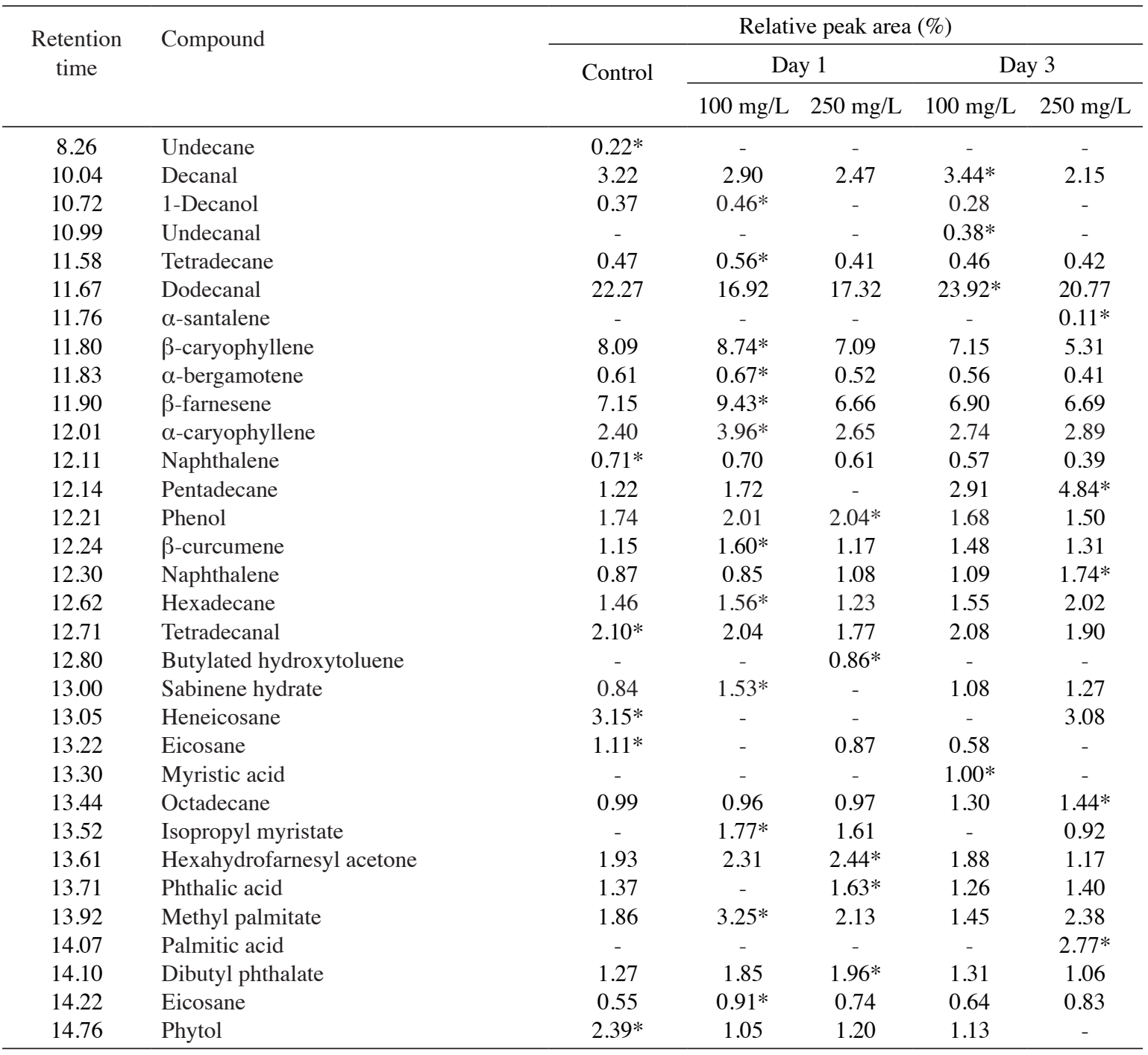

*Compound with the highest relative peak area compare with all treatments

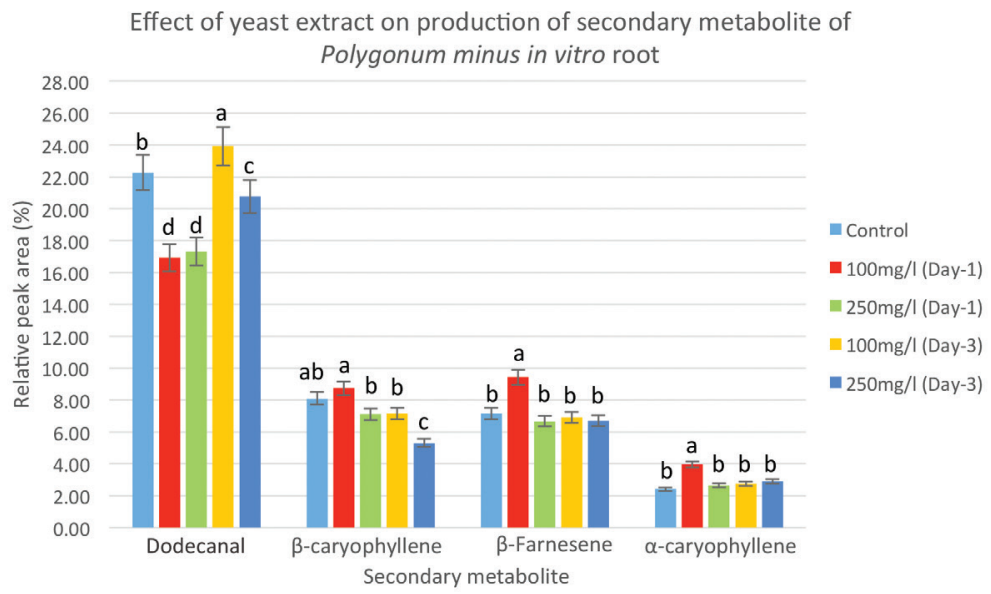

Means within a secondary metabolite with the same letters were not significant at $p \leq 0.05$ according to DMRT

FIGURE 3. Graph on effects of yeast extract on production of four secondary metabolites in Polygonum minus root 
of media. The results from metabolite profile showed that the volatile compound of $P$. minus root produced without any elicitation contained of $50.11 \%$ aliphatic (27.59\% aldehide, $9.17 \%$ alkane and $13.35 \%$ others) and $19.39 \%$ sesquiterpene ( $\beta$-caryophyllene, $\alpha$-bergamotene, $\beta$-farnesene, $\alpha$-caryophyllene and $\beta$-curcumene) in which the dodecanal compound $(22.27 \%)$ and $\beta$-caryophyllene $(8.09 \%)$ had the highest percentage value for aliphatic and sesquiterpene groups, respectively. Moreover, elicitation of $P$. minus root culture using yeast extract at $100 \mathrm{mg} / \mathrm{L}$ concentration for 1 day showed the ability to increase the production of secondary metabolites in many volatile compounds of kesum root including the sesquiterpene compounds compared to control and other yeast extract elicitation treatments ( $\beta$-caryophyllene: $8.09 \%$ to $8.74 \%$; $\beta$-farnesene: $7.15 \%$ to $9.43 \%$; $\alpha$-caryophyllene: $2.40 \%$ to $3.96 \%$ ). Elicitation using $100 \mathrm{mg} / \mathrm{L}$ of yeast extract for 3 days was recorded the best treatment for aldehyde production (Dodecanal: $22.27 \%$ to $23.92 \%$ ).

\section{ACKNOWLEDGEMENTS}

We would like to thank Agricultural Research and Development Institute, Malaysia (MARDI) for granting this study leave and scholarship. Our appreciation goes to Universiti Kebangsaan Malaysia for funding the project (grant code: DPP-2018-010).

\section{REFERENCES}

Abbasi, N.A., Pervaiz, T., Hafiz, I.A., Yaseen, M. \& Hussain, A. 2013. Assessing the response of indigenous loquat cultivar Mardan to phytohormones for in vitro shoot proliferation and rooting. Journal of Zhejiang University Science B 14(9): 774-784.

Ahmad, R., Baharum, S.N., Bunawan, H., Lee, M., Noor, N.M., Rohani, E.R., Ilias, N. \& Zin, N.M. 2014. Volatile profiling of aromatic traditional medicinal plant, Polygonum minus in different tissues and its biological activities. Molecules 19(11): 19220-19242.

Baker, C.M. \& Wetzstein, H.Y. 1994. Influence of auxin type and concentration on peanut somatic embryogenesis. Plant Cell, Tissue and Organ Culture 36(3): 361-368.

Chang, L., Ramireddy, E. \& Schmülling, T. 2013. Lateral root formation and growth of Arabidopsis is redundantly regulated by cytokinin metabolism and signalling genes. Journal of Experimental Botany 64(16): 5021-5032.

Chen, B., Zhang, J., Zhang, W., Zhang, C. \& Xiao, Y. 2015. The rapid propagation technique of the medicinal plant Clinacanthus nutans by tissue culture. New York Science Journal 8: 23-27.

Chen, H. \& Chen, F. 2000. Effects of yeast elicitor on the growth and secondary metabolism of a high-tanshinone-producing line of the Ti transformed Salvia miltiorrhiza cells in suspension culture. Process Biochemistry 35(8): 837-840.

Dallüge, J., Beens, J. \& Udo, A. 2003. Comprehensive twodimensional gas chromatography: A powerful and versatile analytical tool. Journal of Chromatography 1000(1): 69-108.

Davies Jr., F.T. \& Joiner, J.N. 1980. Growth regulator effects on adventitious root formation in leaf bud cuttings of juvenile and mature Ficus pumila. Journal of the American Society for Horticultural Science 105(0): 91-95.

Davies, P. 2013. Plant Hormones: Physiology, Biochemistry and Molecular Biology. Netherlands: Springer Science \& Business Media.

De Alwis, R., Fujita, K., Ashitani, T. \& Kuroda, K.I. 2009. Volatile and non-volatile monoterpenes produced by elicitorstimulated Cupressus lusitanica cultured cells. Journal of Plant Physiology 166(7): 720-728.

Geetha, S.P., Manjula, C., John, C.Z., Minoo, D., Babu, K.N. \& Ravindran, P.N. 2015. Micropropagation of Kaempferia spp. (K. galanga L. and K. rotunda L.). Journal of Spices and Aromatic Crops 6(2): 129-135.

Ghanti, K., Kaviraj, C.P., Venugopal, R.B., Jabeen, F.T.Z. \& Rao, S. 2004. Rapid regeneration of Mentha piperita L. from shoot tip and nodal explants. Indian Journal of Biotechnology 3 : 594-598.

Gor, M.C., Ismail, I., Mustapha, W.A.W., Zainal, Z., Noor, N.M., Othman, R. \& Hussein, Z.A.M. 2011. Identification of CDNAs for jasmonic acid responsive genes in Polygonum minus roots by suppression subtractive hybridization. Acta Physiologiae Plantarum 33(2): 283-294.

Hartmann, H.T., Kester, D.E., Davies, J.F.T. \& Geneve, R.L. 2007. Plant Propagation: Principles and Practices, 7th ed. New Jersey: Prentice-Hall.

Hu, C.Y. \& Wang, P.J. 1983. Meristem, shoot tip and bud cultures. In Handbook of Plant Cell Culture, edited by Evans, D.A., Sharp, W.R., Ammiratto, P.V. \& Yamada, Y. New York: MacMillan. pp. 177-277.

Huda-Faujan, N., Noriham, A., Norrakiah, A. \& Babji, A. 2009. Antioxidant activity of plants methanolic extracts containing phenolic compounds. African Journal of Biotechnology 8(3): 484-489.

Hunter, M.V., Brophy, J.J., Ralph, B.J. \& Elenvenu, F.E. 1997. Composition of Polygonum odoratum Lour. from Southern Australia. Journal of Essential Oil Research 9(5): 603-604.

Husen, A. \& Pal, M. 2007. Metabolic changes during adventitious root primordium development in Tectona grandis Linn. F. (teak) cuttings as affected by age of donor plants and auxin (IBA and NAA) treatment. New Forests 33(3): 309-323.

Ismail,I., Gor, M.C., Mohamed-Hussein,Z.A.,Zainal,Z.\& Noor, N.M. 2011. Alteration of abiotic stress responsive genes in Polygonum minus roots by jasmonic acid elicitation. Plants and Environment. Rijeka, Croatia: InTech-Open Access Company. pp. 49-88.

Jiang, Y., Xia, N., Li, X., Shen, W., Liang, L., Wang, C., Wang, R., Peng, F. \& Xia, B. 2011. Molecular cloning and characterization of a phenylalanine ammonia-lyase gene (LrPAL) from Lycoris radiata. Molecular Biology Reports 38(3): 1935-1940.

Korkina, L. 2007. Phenylpropanoids as naturally occurring antioxidants: From plant defense to human health. Cellular and Molecular Biology 53(1): 15-25.

Martin, K.P., Zhang, C.L., Hembrom, M.E., Slater, A. \& Madassery, J. 2008. Adventitious root induction in Ophiorrhiza prostrata: A tool for the production of camptothecin (an anticancer drug) and rapid propagation. Plant Biotechnology Reports 2(2): 163-169.

Matsuda, H., Shimoda, H., Morikawa, T. \& Yoshikawa, M. 2001. Phytoestrogens from the roots of Polygonum cuspidatum (Polygonaceae): Structure requirement of hydroxyanthraquinones for estrogenic activity. Bioorganic and Medicinal Chemistry Letters 11(14): 1839-1842. 
Mehrotra, S., Goel, M.K., Kukreja, A.K. \& Mishra, B.N. 2007. Efficiency of liquid culture systems over conventional micropropagation: A progress towards commercialization. African Journal of Biotechnology 6(13): 1484-1492.

Mitra, S. 2004. Sample Preparation Techniques in Analytical Chemistry. (Vol. 237). New York: John Wiley \& Sons.

Neumann, K.H., Kumar, A. \& Imani, J. 2009. Plant Cell and Tissue Culture: A Tool in Biotechnology. Verlag, Berlin, Heidelberg: Springer.

Nwe, Y.Y., Myint, K.T., Mochizuki, Y., Vazirzanjani, M., Okayasu, K., Suzuki, S. \& Ogiwara, I. 2014. In vitro regeneration through direct shoot organogenesis in honey orange (Citrus tangerina). Plant Biotechnology 31(4): 341-344.

Poulev, A., O'neal, J.M., Logendra, S., Pouleva, R.B., Timeva, V., Garvey, A.S., Gleba, D., Jenkins, I.S., Halpern, B.T. \& Kneer, R. 2003. Elicitation, a new window into plant chemodiversity and phytochemical drug discovery. Journal of Medicinal Chemistry 46(12): 2542-2547.

Rai, M.K., Jaiswal, V.S. \& Jaiswal, U. 2009. Shoot multiplication and plant regeneration of guava (Psidium guajava L.) from nodal explants of in vitro raised plantlets. Journal of Fruit and Ornamental Plant Research 17(1): 29-38.

Rao, S.R. \& Ravishankar, G. 2002. Plant cell cultures: Chemical factories of secondary metabolites. Biotechnology Advances 20(2): 101-153.

Rong-Min, Y., Na, M., Chun-Yan, Y. \& Yu, Z. 2006. Effects of exogenous phytohormones on hairy root growth of Polygonum multiflorum and biosynthesis of anthraquinones in its hairy root cultures. Chinese Journal of Biotechnology 22(4): 619-623.

Sahu, R., Gangopadhyay, M. \& Dewanjee, S. 2013. Elicitorinduced rosmarinic acid accumulation and secondary metabolism enzyme activities in Solenostemon scutellarioides. Acta Physiologiae Plantarum 35(5): 1473-1481.

Sandal, I., Bhattacharya, A. \& Ahuja, P.S. 2001. An efficient liquid culture system for tea shoot proliferation. Plant Cell, Tissue and Organ Culture 65: 75-80.

Shukor, M.F.A., Ismail, I., Zainal, Z. \& Noor, N.M. 2013. Development of a Polygonum minus cell suspension culture system and analysis of secondary metabolites enhanced by elicitation. Acta Physiologiae Plantarum 35(5): 1675-1689.

Singh, J., Gupta, S. \& Khoshe, P. 2014. In vitro regeneration of pomegranate (Punicagranatum L.) from nodal explant. International Journal of Advances in Pharmacy, Biology and Chemistry 3(3): 734-736.
Vikram,P., Chiruvella, K.K., Ripain, I.H.A. \& Arifullah, M. 2014. A recent review on phytochemical constituents and medicinal properties of kesum (Polygonum minus Huds.). Asian Pacific Journal of Tropical Biomedicine 4(6): 430-435.

Vimala, S., Ilham, M., Rashih, A., Rohana, S. \& Juliza, M. 2006. Antioxidant and skin whitening standardised extracts: Cosmeceutical and neutraceutical product development and commercialisation in FRIM. Sustainable Management and Utilization of Medicinal Plant Resources: Proceedings of the International Conference on Medicinal Plants. pp. 280-287.

Vinothkumar, D. \& Senthilkumar, M. 2015. In vitro callus induction and plants from leaf explants of Wattakaka volubilis L. (Staf. Arn) - A vulnerable medicinal plant. European Journal of Biotechnology and Bioscience 3(6): 12-16.

Wang, Y.D., Wu, J.C. \& Yuan, Y.J. 2007. Salicylic acid-induced taxol production and isopentenyl pyrophosphate biosynthesis in suspension cultures of Taxus chinensis var. Mairei. Cell Biology International 31(10): 1179-1183.

Yaacob, K. 1987. Kesom oil - A natural source of aliphatic aldehydes. Perfumer \& Flavorist 12: 27-30.

Young-Am, C., Yu, H.S., Song, J.S., Chun, H.K. \& Park, S.U. 2000. Indigo production in hairy root cultures of Polygonum tinctorium Lour. Biotechnology Letters 22(19): 1527-1530.

Zhao, J., Davis, L.C. \& Verpoorte, R. 2005. Elicitor signal transduction leading to production of plant secondary metabolites. Biotechnology Advances 23(4): 283-333.

Mohd Azhar Hassan*, Ahmad Hafiz Baharom, Muhammad Shafie Md Sah \& Mohamad Zulkiffely A. Rahman

MARDI Headquarters

Persiaran MARDI-UPM

43400 Serdang, Selangor Darul Ehsan

Malaysia

Mariatulqabtiah Abdul Razak

Universiti Putra Malaysia

43400 Serdang, Selangor Darul Ehsan

Malaysia

*Corresponding author; email: mazhar@mardi.gov.my

Received: 30 May 2018

Accepted: 18 September 2018 